\title{
Rapid Formation of Stem Cell Spheroids Using Two-Dimensional MXene Particles
}

\author{
JunHwee Jang $(\mathbb{D}$ and Eun-Jung Lee * \\ A Department of Nano-Biomedical Science \& BK21 PLUS NBM Global Research Center for Regenerative \\ Medicine, Dankook University, Cheonan 31116, Korea; junhweej@dankook.ac.kr \\ * Correspondence: leeej@dankook.ac.kr; Tel.: +82-41-550-3697
}

check for updates

Citation: Jang, J.; Lee, E.-J. Rapid Formation of Stem Cell Spheroids Using Two-Dimensional MXene Particles. Processes 2021, 9, 957. https://doi.org/10.3390/pr9060957

Academic Editor: Inmaculada Posadas Mayo

Received: 16 April 2021

Accepted: 26 May 2021

Published: 28 May 2021

Publisher's Note: MDPI stays neutral with regard to jurisdictional claims in published maps and institutional affiliations.

Copyright: (c) 2021 by the authors. Licensee MDPI, Basel, Switzerland. This article is an open access article distributed under the terms and conditions of the Creative Commons Attribution (CC BY) license (https:// creativecommons.org/licenses/by/ $4.0 /)$

\begin{abstract}
Cell spheroids have been studied as a biomimic medicine for tissue healing using cell sources. Rapid cell spheroid production increases cell survival and activity as well as the efficiency of mass production by reducing processing time. In this study, two-dimensional MXene $\left(\mathrm{Ti}_{3} \mathrm{C}_{2}\right)$ particles were used to form mesenchymal stem cell spheroids, and the optimal MXene concentration, spheroid-production times, and bioactivity levels of spheroid cells during this process were assessed. A MXene concentration range of 1 to $10 \mu \mathrm{g} / \mathrm{mL}$ induced spheroid formation within $6 \mathrm{~h}$. The MXeneinduced spheroids exhibited osteogenic-differentiation behavior, with the highest activity levels at a concentration of $5 \mu \mathrm{g} / \mathrm{mL}$. We report a novel and effective method for the rapid formation of stem cell spheroids using MXene.
\end{abstract}

Keywords: MXene; cell spheroid; rapid formation; mesenchymal stem cells; osteogenic differentiation

\section{Introduction}

Cell-adhesion agents are crucial in cell-spheroid formation to ensure cell function while maintaining volume [1]. Cell spheroids are spherical organ mimics that form during in vitro culture [2]. They provide a three-dimensional (3D) culture environment that more closely resembles the actual in vivo environment physiologically compared with a twodimensional (2D) monolayer culture, which improves the viability and functionality of the cells that make up the spheroids [3]. Moreover, niche components of the cellular microenvironment, signaling pathways, and cell manipulation by genetic engineering are very simple, so they play an important role that is intermediate between those of traditional 2D culture and in vivo animal/human models [4]. Cell spheroids have been applied to various fields, such as evaluations of tumor therapeutic efficacy, mechanisms of carcinogenesis, cell necrosis using genetic function analysis, interactions between cells during cell differentiation, and 3D organ bioprinting [5-7]. To this end, research has been conducted on spheroid production and analysis and the development of efficient spheroid formation methods [8]. One goal is rapid spheroid formation using biomaterials to support cell-to-cell adhesion.

Tissue engineering biomaterials are widely applied to improve efficiency or functionality, such as to enhance process efficiency or biocompatibility with cells or tissues or to modify and improve the function of tissue-engineered devices [9]. Several researchers performed cell-spheroid production via microwells composed of biocompatible materials for controlling the spheroid size and formation time $[10,11]$. In addition, some studies have examined the use of graphene and silicate for cell-spheroid production [12,13]. Kim et al. used graphene oxide to improve intercellular adhesion efficiency to produce cell spheroids and report their differentiation properties [14]. Yamaguchi et al. suggested adding nanosized silicates to the production of spheroids because silicates contribute to facilitating osteogenic differentiation by silicon ions as well as fabricating cell spheroids [15]. There were studies that conjugate drugs to functional groups of graphene material to enhance the survival and differentiation of cells within the spheroids $[15,16]$. 
Discovered in 2011, MXene is recently attracting attention as a biomaterial that can replace graphene with similar structures due to its two-dimensional structure [17]. $\mathrm{Ti}_{3} \mathrm{C}_{2}$ MXene is being used increasingly in tissue engineering, bioimaging, and sensors due to its biocompatibility, biodegradability, and antibacterial and near-infrared photothermal properties [18]. MXenes have been composed of other biomaterials for improved bone regeneration due to their good mechanical properties for bioengineering [19]. Despite the interest as a biomedical material, little is reported about the interactions of MXenes with stem cells or biomolecules. MXenes spontaneously form lamellar stacked structures, which increase the available surface area for drug attachment compared to single-layered MXene flakes and reduce cell damage caused by direct contact with 2D MXene [20]. Moreover, the 2D structure of MXene and its hydrophilic functional groups improve cell viability and facilitate combination with cells, while its biodegradability eliminates obstacles caused by material remaining in a spheroid culture [21].

Therefore, this study investigated the potential of producing stem cell spheroids using MXene as a cell-adhesion agent. We investigated whether and when stem cell spheroids are formed, the shape of the spheroids, and the biological activity of the cells and provide information on the optimal concentration of MXene for spheroid formation and bioactivity. This should enable the advancement of research on new highly bio-responsive organoids based on MXene bioceramics.

\section{Materials and Methods}

\subsection{Materials Preparation}

The following materials were purchased from various companies. Fetal bovine serum (FBS, 12483-020, Gibco, Eri County, NY, USA), penicillin/streptomycin (P/S, 15140-122, ThermoFisher, Waltham, MA, USA), alpha Modified Eagle Medium (Alpha MEM, LM008-01, WELGENE, Gyeongsan-si, Korea), MTS kit (G3580, Promega, Madison, WI, USA), paraformaldehyde (PFA, Sigma-Aldrich, St. Louis, MO, USA), phalloidin alexa 488 (ThermoFisher Scientific, Waltham, MA, USA), Alkaline Phosphatase (ALP) detection kit (K412500, Biovision, Milpitas, CA, USA), Bradford assay kit (ThermoFisher Scientific, Waltham, MA, USA), Alizarin Red S (ARS, Sigma-Aldrich, St. Louis, MO, USA). $\mathrm{Ti}_{3} \mathrm{C}_{2}$ MXene (MX20A-003, Invisible, Korea) with stacked lamellar structure was purchased from Korea. The average particle size of MXene was 2 to $5 \mathrm{um}$. Human mesenchymal stem cells (hMSC, A15652, Gibco, Eri County, NY, USA) were cultured at $37{ }^{\circ} \mathrm{C}$ under $5 \% \mathrm{CO}_{2}$ in culture media. The cell culture media was prepared by adding $10 \%$ fetal bovine serum and $1 \%$ antibiotics containing 10,000 units of penicillin and streptomycin to Alpha Modified Eagle Medium. The hMSC of third to fourth passages was used in the experiments in this study. The bone differentiation assessment was executed using the cell culture medium without using an osteogenic differentiation medium.

\subsection{MXene-Induced Stem Cell-Spheroid Formation and Evaluation}

Polydimethylsiloxane-coated culture plates were prepared to prevent cell adhesion [22] to make human mesenchymal stem cell (hMSC) spheroids using 2D MXene. A medium containing cell at densities of 20,000-50,000 cells/mL was poured into each plate and treated MXene suspensions with $0-10 \mu \mathrm{g} / \mathrm{mL}$ concentrations. The cell and MXene suspensions were cultured on a 3D rocking shaker at $50 \mathrm{rpm}$ in an incubator. Spheroid formation was observed as a function of the culture time. The spheroid-formation time, spheroid size, and cell survivability in the spheroids formed with MXene were characterized.

\subsection{Testing for Cell Viability}

Cell viability and differentiation behavior induced by MXene were investigated for spheroids produced after $24 \mathrm{~h}$ with a density of 20,000 cells/mL. Compressed spheroids without MXene were not reliably obtained within $24 \mathrm{~h}$ and were excluded for the cellular evaluation. As prepared, the viability of the spheroid-formed cells was observed via Live/Dead staining and MTS assay. For fluorescence visualization, the MSCs were fixed 
on Days 1 and 3 by adding 4\% paraformaldehyde (PFA) and treating with Triton X-100 for $10 \mathrm{~min}$. They were then reacted with $200 \mu \mathrm{L}$ Alexa 488 phalloidin solution for $1 \mathrm{~h}$ in each well. Once the reactions were completed, samples were rinsed with phosphate buffer saline (PBS) and monitored using confocal laser scanning microscopy (CLSM, Zeiss, Germany). Cell proliferation was evaluated for 1 and 3 days, and it proceeded according to the manual of the MTS kit (G3580, Promega, Madison, WI, USA)

\subsection{Osteogenic Differentiation}

The cells that migrated from the spheroids were visualized microscopically, and their osteogenic differentiation was evaluated using an ALP detection kit and Alizarin red stain (ARS). For the ALP activity assay, the cell spheroids were cultured for 7 days. The cells were rinsed with PBS and lysed with Triton X-100. The protein quantity was determined by the Bradford assay kit, and an equal amount of samples were reacted with paranitrophenyl phosphate (pNPP) and then measured at $405 \mathrm{~nm}$ wavelength. For the ARS assay, the cells cultured for 14 days were washed twice in Dulbecco's phosphate-buffered saline, fixed in $4 \%$ paraformaldehyde for $15 \mathrm{~min}$, and dyed with $2 \%$ ARS. The dyed cells were washed three times with distilled water and dried at room temperature. The dyed cells were stirred with $10 \%$ acetic acid for $30 \mathrm{~min}$, and the pellet was heated at $90{ }^{\circ} \mathrm{C}$ for $15 \mathrm{~min}$ to quantify the ARS level. After cooling on ice for $10 \mathrm{~min}$, the solution was neutralized with ammonium hydroxide, and the absorbance was measured at $405 \mathrm{~nm}$ [23].

\subsection{Statistical Analysis}

All quantitative results were collected in at least three replicates from each test group. The statistical analyses were performed using a t-test, and comparisons between groups were analyzed by one-way analysis of variance test. The differences with a $p$-value $<0.01$ were considered statistically significant $\left.{ }^{* *} p<0.01,{ }^{* * *} p<0.001\right)$.

\section{Results and Discussion}

\subsection{Cell Spheroids Induced by MXene Adhesive}

Figure 1A shows a schematic diagram of the method used to produce cell spheroids rapidly with MXene. We observed that the presence of MXene particles during the culture of stem cells attached to the cytoplasm and continued to move with the cells during cell migration (Supplementary Video S1). It is supposed to have been caused by the excellent compatibility of the cell adhesion-associated proteins due to its hydrophilicity and biocompatibility of MXene. Herein, this observation data led us to study whether MXene can act as a cell adhesive to the production of spheroids formed by cell aggregation and intercellular adhesion. With this method, the spheroid size and formation time depend on the process conditions, such as the cell density and shaking speed. First, we investigated the shaking speeds at which spheroids form quickly (Figure 1B). At $50 \mathrm{rpm}$, spheroids formed in $8 \mathrm{~h}$, whereas at $80 \mathrm{rpm}$, small cell aggregates occurred, but no spheroids formed.

\subsection{Cell Spheroids Formation Time}

For spheroid production, hMSCs at initial densities of 20,000 to 50,000 cells/mL were used with MXene concentrations of 0 to $10 \mu \mathrm{g} / \mathrm{mL}$. The process of cell spheroid formation according to MXene concentration, cell density, and culture time was observed through a microscope (Figure S1), and the formation time and spheroid size investigated by the microscope are shown in Figure 2A,B. As a result of the formation time (Figure 2A), without MXene, cells at low density did not form spheroids, whereas spheroid formation took more than $20 \mathrm{~h}$ when a density of more than 40,000 cells $/ \mathrm{mL}$ was used. The $0.5 \mu \mathrm{g} / \mathrm{mL}$ MXene concentration did not contribute to the rapid formation of spheroids. At MXene concentrations above $1 \mu \mathrm{g} / \mathrm{mL}$, hMSC spheroids formed within 4 to $6 \mathrm{~h}$. With an initial density of 20,000 cells $/ \mathrm{mL}$, spheroids formed within $4 \mathrm{~h}$ regardless of the amount of MXene (range 1-10 $\mu \mathrm{g} / \mathrm{mL}$ ). Typically, spheroid fabrication takes 1 to 7 days, but the use of MXene 
dramatically reduced the formation time, with the best results obtained with a density of 20,000 cells $/ \mathrm{mL}$ and 1-10 $\mathrm{\mu g} / \mathrm{mL}$ MXene.

(A)

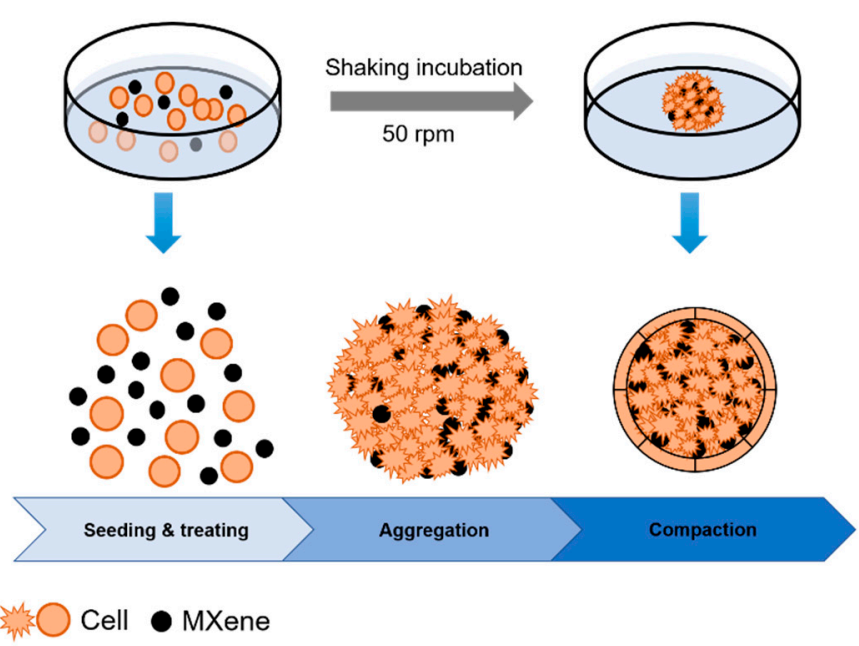

(B)

0

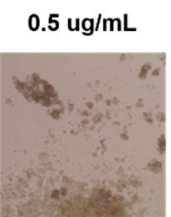

50 RPM

$2 \mathrm{~h}$

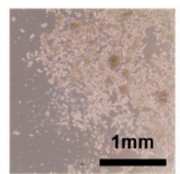

$8 \mathrm{~h}$
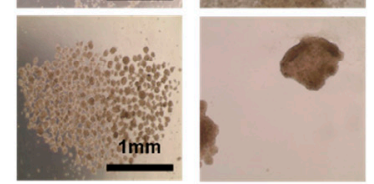

$1 \mathrm{ug} / \mathrm{mL}$

$5 \mathrm{ug} / \mathrm{mL}$

$10 \mathrm{ug} / \mathrm{mL}$
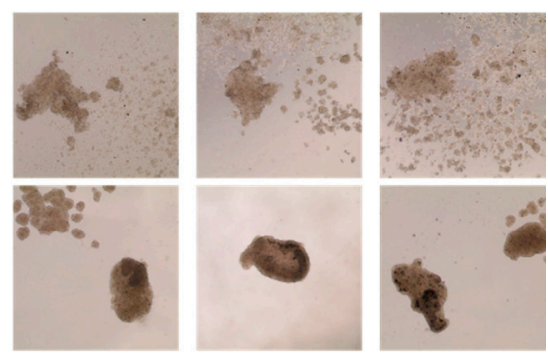

$2 \mathrm{~h}$
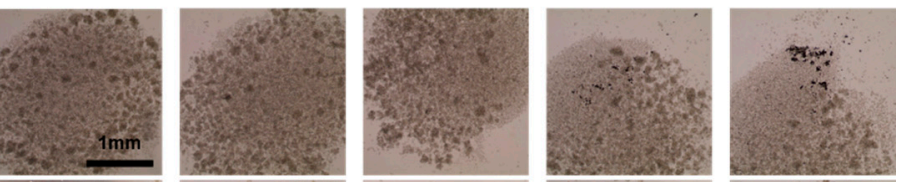

80 RPM
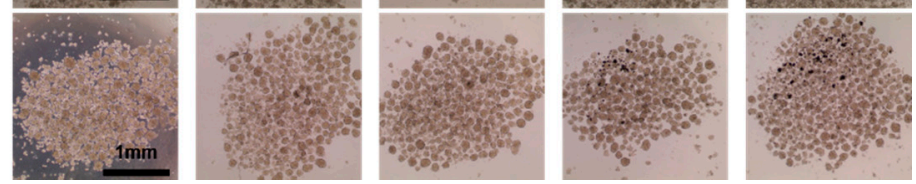

Figure 1. Schematic diagram of a method for rapidly producing cell spheroids using MXene (A). Spheroid formation according to MXene concentration and shaking speed (B).

\subsection{Cell Spheroid Compaction}

After spheroid formation by cell aggregation, spheroid compaction occurs. The degree of compaction during the 24-h incubation was observed by examining the decrease in diameter between spheroids incubated for 12 and $24 \mathrm{~h}$ (Figure 2B). The compaction was the greatest at $1 \mu \mathrm{g} / \mathrm{mL}$ MXene, and less compaction was observed with higher cell densities. For the same cell density, the degree of spheroid compaction was relatively high with low MXene concentrations. Compaction is induced by homophilic binding between cadherins in the cell membranes [22]. MXene can hinder the cadherin-cadherin interaction between cells, so homophilic binding occurs more efficiently at low MXene concentrations [24]. 


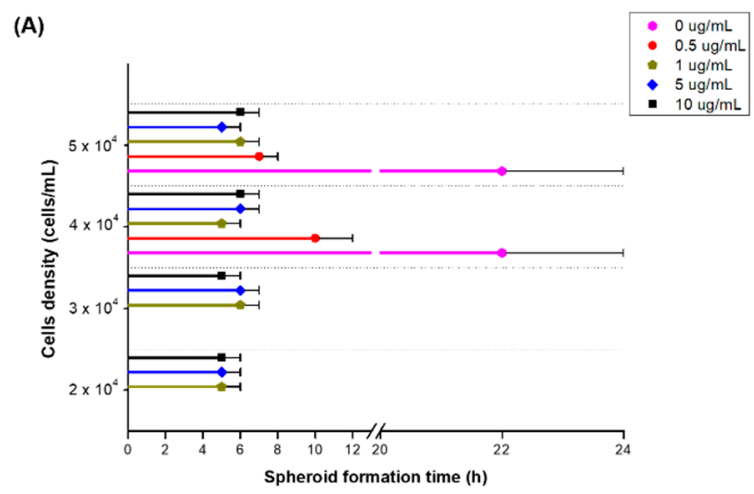

(B)

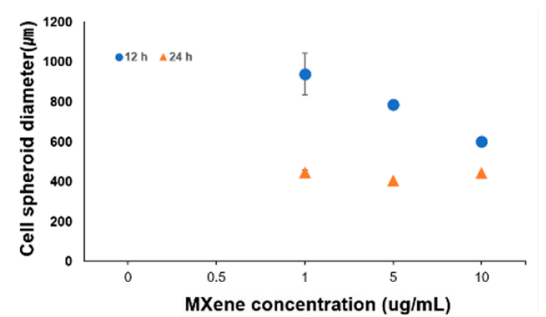

(D)

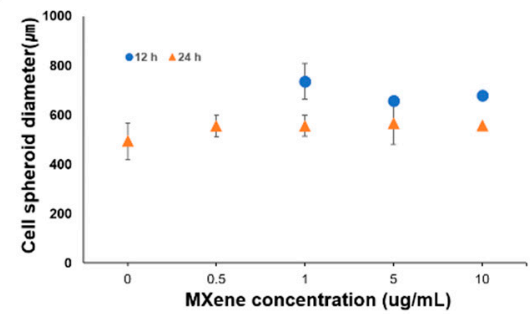

(C)

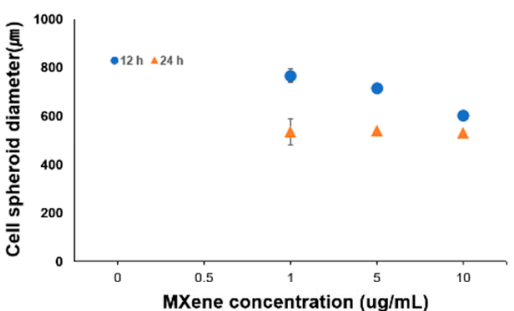

(E)

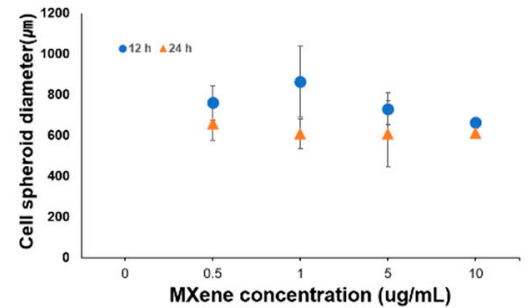

Figure 2. Spheroid-formation times at different MXene and hMSC concentrations (A). Cell-spheroid diameters composed of different cell density after culture for 12 and $24 \mathrm{~h} ; 2 \times 10^{4}$ cells $/ \mathrm{mL}$ (B), $3 \times 10^{4}$ cells $/ \mathrm{mL}(\mathbf{C}), 4 \times 10^{4}$ cells $/ \mathrm{mL}(\mathbf{D}), 5 \times 10^{4}$ cells $/ \mathrm{mL}(\mathbf{E})$.

\subsection{Cytotoxicity and Proliferation}

The viability of the cells that formed spheroids was evaluated by CLSM observation and MTS metabolism. Images showed that, in all spheroids, cells kept their viability without showing cell death. The representative CLSM image is present in Figure 3A. Figure 3B shows MTS metabolism of cells that form the spheroid for 3 days of culture. The cells well grew in all spheroids without any sign of cytotoxicity, and the results showed that the best proliferation rate was revealed in the spheroid containing $10 \mu \mathrm{g} / \mathrm{mL}$ MXene for 3 days. Cells in compact spheroids over $500 \mu \mathrm{m}$ in diameter migrated and grew well, and most cells from spheroids with $5 \mu \mathrm{g} / \mathrm{mL}$ MXene spread well, with no dead cells after 7 days of culture (Figure 3C). This indicates that there were no necrotic cores, which is generally a problem for spheroids larger than $500 \mu \mathrm{m}$ in diameter. 
(A)
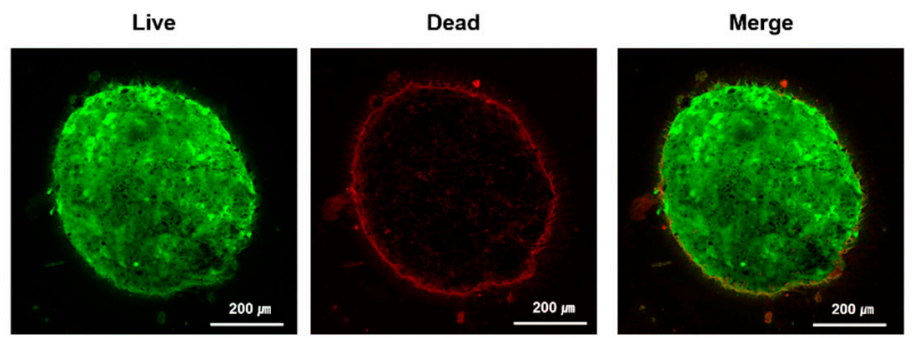

(B)

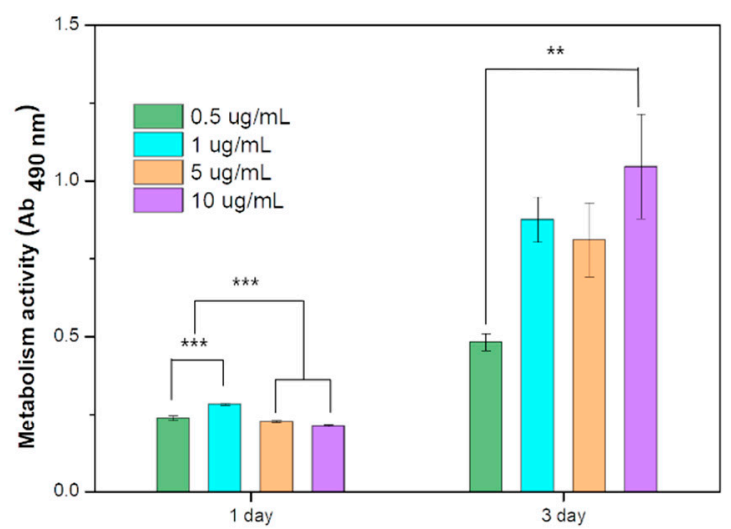

(C)

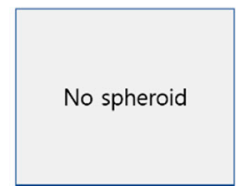

$0.5 \mathrm{ug} / \mathrm{mL}$

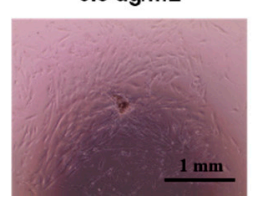

$1 \mathrm{ug} / \mathrm{mL}$

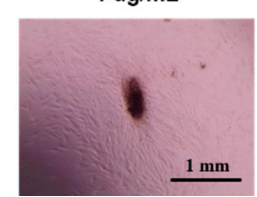

$5 \mathrm{ug} / \mathrm{mL}$

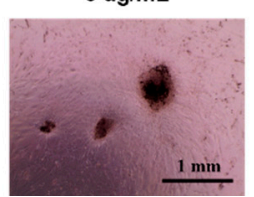

$10 \mathrm{ug} / \mathrm{mL}$

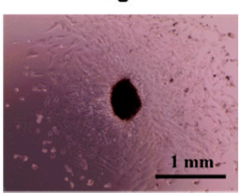

Figure 3. In vitro cell test results. Cell viability observed by CLSM (A). MTS metabolism of hMSCs after 1 and 3 days of cultures $(\mathbf{B})\left(^{* * *} p<0.001\right.$ and $\left.{ }^{* *} p<0.01\right)$. Microscopy images of cell migration and spheroid growth with an initial density of 20,000 cells $/ \mathrm{mL}$ after 7 days of culture (C).

\subsection{Osteogenic Differentiation}

Mesenchymal stem cells can self-renew and differentiate into bone-forming cells, which is very useful for bone tissue repair and regeneration. MXenes are Ti-based, which should facilitate new bone growth [25]. Thus, the spheroids produced using MXene were expected to promote osteogenic differentiation, and the present study investigated the osteogenic differentiation level.

ALP activities from cells cultured for 7 days are presented in Figure 4A. The cells of spheroids containing $5 \mu \mathrm{g} / \mathrm{mL}$ MXene showed a highly statistically significant increase in ALP activities, while the spheroid containing $10 \mu \mathrm{g} / \mathrm{mL}$ MXene revealed the reduction level of ALP. The mineralization of cell and extracellular matrix is an indicator for the last stage of bone differentiation. In general, ARS expression tends to increase after a long incubation period. As shown in the results of the study in Figure 4B, the mineral formation showed significantly higher levels in cells of the 14-day cultured spheroids than in the 7-day cultured spheroids. Particularly, the MXene-induced spheroids that formed at cell densities at which there was no spheroid formation without MXene exhibited osteogenicdifferentiation behavior, with the greatest activity observed with $5 \mu \mathrm{g} / \mathrm{mL}$ MXene. The use of MXene facilitated the formation and osteogenic differentiation of spheroids.

Although studies that are more detailed are needed to examine spheroid characterizations and changes in the physical properties of spheroids resulting from the stiffness of MXene and their differentiation, this study is the first to suggest the utility of MXene in promoting cell spheroid formation using its cell affinity. 
(A)

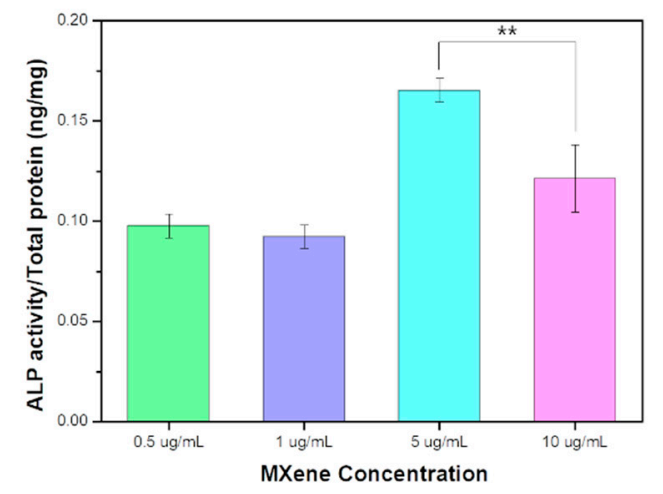

(B)

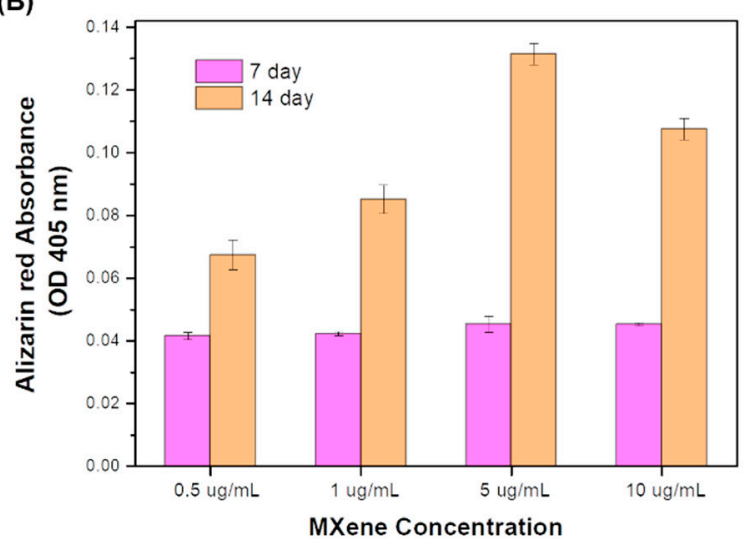

Figure 4. Osteogenic differentiation in spheroids with different MXene concentrations assessed by ALP activity (A) and ARS assay (B) $(* * p<0.01)$.

\section{Conclusions}

Two-dimensional MXene particles were used as a cell-adhesion agent to produce mesenchymal stem cell spheroids. At concentrations greater than $1 \mu \mathrm{g} / \mathrm{mL}, \mathrm{MXene}$ induced spheroid formation within $6 \mathrm{~h}$. At low cell densities, the MXene-induced spheroids were over $500 \mu \mathrm{m}$ in diameter and did not have necrotic cores. The spheroids produced with MXene promoted osteogenic differentiation without requiring an osteogenic medium, and the highest production rate was at an MXene concentration of $5 \mu \mathrm{g} / \mathrm{mL}$. These findings should aid the development of a new, economical way to form organoids using MXene as a cell-adhesion agent to produce spheroid-laden bioink for tissue-engineered constructs.

Supplementary Materials: The following are available online at https:/ /www.mdpi.com/article/10 $.3390 /$ pr9060957/s1, Figure S1: Observation of cell spheroids formation corresponding to MXene concentration, stem cell density and culture time of 2, 4, 6, 8, 10, 12, and 24 h. (S2.a-S2.g), Video S1: Video showing interaction between MXene particles and human mesenchymal stem cells (hMSCs).

Author Contributions: Conceptualization, E.-J.L.; methodology, J.J.; investigation, E.-J.L. and J.J.; writing-original draft preparation, E.-J.L. and J.J.; writing-review and editing, E.-J.L. and J.J.; supervision, E.-J.L.; project administration, E.-J.L.; funding acquisition, E.-J.L. All authors have read and agreed to the published version of the manuscript.

Funding: This work was supported by the National Research Foundation of Korea (NRF-2020R1A2C 1012454).

Institutional Review Board Statement: Not applicable.

Informed Consent Statement: Not applicable. 
Conflicts of Interest: The authors declare no conflict of interest. The funders had no role in the design of the study; in the collection, analyses, or interpretation of data; in the writing of the manuscript, or in the decision to publish the results.

\section{References}

1. Lee, Y.B.; Kim, E.M.; Byun, H.; Chang, H.-K.; Jeong, K.; Aman, Z.M.; Choi, Y.S.; Park, J.; Shin, H. Engineering spheroids potentiating cell-cell and cell-ECM interactions by self-assembly of stem cell microlayer. Biomaterials 2018, 165, 105-120. [CrossRef] [PubMed]

2. Rezende, R.A.; Pereira, F.D.A.S.; Kasyanov, V.; Kemmoku, D.T.; Maia, I.; da Silva, J.V.L.; Mironov, V. Scalable Biofabrication of Tissue Spheroids for Organ Printing. Procedia CIRP 2013, 5, 276-281. [CrossRef]

3. Petrenko, Y.; Syková, E.; Kubinová, Š. The therapeutic potential of three-dimensional multipotent mesenchymal stromal cell spheroids. Stem Cell Res. Ther. 2017, 8, 94. [CrossRef] [PubMed]

4. $\quad$ Rodrigues, T.; Kundu, B.; Silva-Correia, J.; Kundu, S.C.; Oliveira, J.M.; Reis, R.L.; Correlo, V.M. Emerging tumor spheroids technologies for 3D in vitro cancer modeling. Pharmacol. Ther. 2018, 184, 201-211. [CrossRef] [PubMed]

5. Zanoni, M.; Piccinini, F.; Arienti, C.; Zamagni, A.; Santi, S.; Polico, R.; Bevilacqua, A.; Tesei, A. 3D tumor spheroid models for in vitro therapeutic screening: A systematic approach to enhance the biological relevance of data obtained. Sci. Rep. 2016, 6, 19103. [CrossRef] [PubMed]

6. Huang, B.-W.; Gao, J.-Q. Application of 3D cultured multicellular spheroid tumor models in tumor-targeted drug delivery system research. J. Control. Release 2018, 270, 246-259. [CrossRef] [PubMed]

7. Nath, S.; Devi, G.R. Three-dimensional culture systems in cancer research: Focus on tumor spheroid model. Pharmacol. Ther. 2016, 163, 94-108. [CrossRef]

8. Ryu, N.-E.; Lee, S.-H.; Park, H. Spheroid Culture System Methods and Applications for Mesenchymal Stem Cells. Cells 2019, 8, 1620. [CrossRef]

9. O'Brien, F.J. Biomaterials \& scaffolds for tissue engineering. Mater. Today 2011, 14, 88-95. [CrossRef]

10. Ge, Z.; Zhao, J.; Yu, H.; Yang, W.; Zhou, P.; Wang, Z.; Liu, L. Biomimetic construction of peritoneum to imitate peritoneal metastasis using digital micromirror device-based optical projection lithography. Lab Chip 2020, 20, 3109-3119. [CrossRef]

11. Yang, W.; Yu, H.; Li, G.; Wei, F.; Wang, Y.; Liu, L. Mask-free fabrication of a versatile microwell chip for multidimensional cellular analysis and drug screening. Lab Chip 2017, 17, 4243-4252. [CrossRef] [PubMed]

12. Shin, S.R.; Li, Y.-C.; Jang, H.L.; Khoshakhlagh, P.; Akbari, M.; Nasajpour, A.; Zhang, Y.S.; Tamayol, A.; Khademhosseini, A. Graphene-based materials for tissue engineering. Adv. Drug Deliv. Rev. 2016, 105, 255-274. [CrossRef]

13. Lou, Y.-R.; Kanninen, L.; Kaehr, B.; Townson, J.L.; Niklander, J.; Harjumäki, R.; Jeffrey Brinker, C.; Yliperttula, M. Silica bioreplication preserves three-dimensional spheroid structures of human pluripotent stem cells and HepG2 cells. Sci. Rep. 2015, 5, 13635. [CrossRef]

14. Yamaguchi, Y.; Deng, D.; Sato, Y.; Hou, Y.T.; Watanabe, R.; Sasaki, K.; Kawabe, M.; Hirano, E.; Morinaga, T. Silicate fiber-based 3D cell culture system for anticancer drug screening. Anticancer Res. 2013, 33, 5301-5309. [PubMed]

15. Kim, C.-H.; Suhito, I.R.; Angeline, N.; Han, Y.; Son, H.; Luo, Z.; Kim, T.-H. Vertically Coated Graphene Oxide Micro-Well Arrays for Highly Efficient Cancer Spheroid Formation and Drug Screening. Adv. Healthc. Mater. 2020, 9, 1901751. [CrossRef] [PubMed]

16. Kim, C.-H.; Kim, T.-H. Graphene Hybrid Materials for Controlling Cellular Microenvironments. Materials 2020, $13,4008$. [CrossRef]

17. Naguib, M.; Kurtoglu, M.; Presser, V.; Lu, J.; Niu, J.; Heon, M.; Hultman, L.; Gogotsi, Y.; Barsoum, M.W. Two-Dimensional Nanocrystals Produced by Exfoliation of Ti3AlC2. Adv. Mater. 2011, 23, 4248-4253. [CrossRef]

18. Huang, Z.; Cui, X.; Li, S.; Wei, J.; Li, P.; Wang, Y.; Lee, C.-S. Two-dimensional MXene-based materials for photothermal therapy. Nanophotonics 2020, 9, 2233-2249. [CrossRef]

19. Yang, Q.; Yin, H.; Xu, T.; Zhu, D.; Yin, J.; Chen, Y.; Yu, X.; Gao, J.; Zhang, C.; Chen, Y.; et al. Engineering 2D Mesoporous Silica@MXene-Integrated 3D-Printing Scaffolds for Combinatory Osteosarcoma Therapy and NO-Augmented Bone Regeneration. Small 2020, 16, 1906814. [CrossRef]

20. Rasool, K.; Helal, M.; Ali, A.; Ren, C.E.; Gogotsi, Y.; Mahmoud, K.A. Antibacterial Activity of $\mathrm{Ti}_{3} \mathrm{C}_{2} \mathrm{~T}_{\mathrm{x}} \mathrm{MXene.} \mathrm{ACS} \mathrm{Nano} \mathrm{2016,} \mathrm{10,}$ 3674-3684. [CrossRef]

21. George, S.M.; Kandasubramanian, B. Advancements in MXene-Polymer composites for various biomedical applications. Ceram. Int. 2020, 46, 8522-8535. [CrossRef]

22. Cesarz, Z.; Tamama, K. Spheroid Culture of Mesenchymal Stem Cells. Stem Cells Int. 2016, 2016, 9176357. [CrossRef] [PubMed]

23. Gregory, C.A.; Grady Gunn, W.; Peister, A.; Prockop, D.J. An Alizarin red-based assay of mineralization by adherent cells in culture: Comparison with cetylpyridinium chloride extraction. Anal. Biochem. 2004, 329, 77-84. [CrossRef]

24. Conacci-Sorrell, M.; Simcha, I.; Ben-Yedidia, T.; Blechman, J.; Savagner, P.; Ben-Ze'ev, A. Autoregulation of E-cadherin expression by cadherin-cadherin interactions: The roles of beta-catenin signaling, Slug, and mapk. J. Cell Biol. 2003, 163, 847-857. [CrossRef] [PubMed]

25. Kubota, S.; Johkura, K.; Asanuma, K.; Okouchi, Y.; Ogiwara, N.; Sasaki, K.; Kasuga, T. Titanium oxide nanotubes for bone regeneration. J. Mater. Sci. Mater. Med. 2004, 15, 1031-1035. [CrossRef] [PubMed] 